\title{
弇 Analysis of Abrasion in Coastal Areas of North Bengkulu Beach as Learning Material for Disaster Mitigation
}

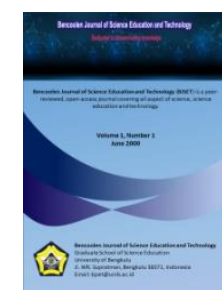

\author{
Jenny Maya Yazalia*, Henny Johan, Rendy W. Wardana \\ Graduate School of Science Education, University of Bengkulu \\ *Email: jennymayayazalia39@gmail.com
}

DOI: https://doi.org/10.33369/bjset.1.2.55-60

\begin{abstract}
The threat of disasters that often occur in coastal areas is seawater abrasion. One of the provinces in Indonesia which is located in the coastal region is Bengkulu with the area most prone to abrasion disaster is the North Bengkulu Regency. This study aims to describe the potential for abrasion in the North Bengkulu region based on the parameters of abrasion vulnerability. The research method used is a qualitative descriptive method with literature studies. An abrasion potential analysis has been carried out based on the measurement of three parameters of abrasion susceptibility namely coastal morphology, soil structure and wave height. The results showed that the coastal morphology in the area of North Bengkulu Regency was strongly influenced by tectonic processes that occur due to subduction zone pressure. Coastal morphology in the form of steep cliffs, piles (stack), while on steep cliffs also formed beach caves. The soil structure on a coastal cliff shows that the dominant cliff is composed of sandstones, gravel, clay and alluvium. The difference in vertical rock resistance results in the beach being prone to abrasion. The wave height (swash) in the North Bengkulu regency is an average of $60 \mathrm{~cm}$, although at certain locations the swash height reaches $85 \mathrm{~cm}$. Thus, it can be concluded that the area of North Bengkulu regency is very potential for abrasion and efforts are needed to reduce it, one of the ways through disaster mitigation education.
\end{abstract}

Keywords: Abrasion Potential; Parameters of Abrasion Susceptibility; Qualitative Descriptive.

\section{INTRODUCTION}

Indonesia is an archipelagic country and has a fairly wide area, with a coastline of approximately $81,000 \mathrm{~km}$, besides that Indonesia is also a country with a fairly high population that partly lives in coastal areas. One of the provinces in Indonesia located in the coastal region is Bengkulu. Bengkulu's geographical position is located on the west coast of the island of Sumatra, which is directly opposite the Indian Ocean. The threat of disasters that often occur in coastal areas, besides those of a sudden nature such as earthquakes, tsunamis, tidal waves and others, there is also a threat that is slowly but surely a coastal abrasion. According to BNPB (2014) about the disaster risk index that the Bengkulu region most vulnerable to coastal abrasion disasters is Bengkulu Utara Regency. This was also proven in Nofirman's research (2017) that areas along the North Bengkulu coast such as Cipta Mulya beach (Putri Hijau), Air Petai Beach (Putri Hijau), Urai beach (Ketahun), Sengarai beach (Ketahun), Bintunan beach (Batiknau) Palik Market (Iron Water) beach and Coastal Beach (Air Napal) beach abrasion disaster has occurred. 
Coastal abrasion is actually a form of imbalance of interactions between oceanographic and geological factors in coastal areas. Oceanographic factors include waves, tides and currents, while geological factors include coastal constituent rocks and coastal morphology. In the condition that oceanographic factors are stronger than geological factors, the beach will experience abrasion (Morton 2004). The phenomenon of abrasion in the area of North Bengkulu Regency has visibly caused losses to the residential neighborhoods, cross-west Sumatra road facilities, and the community plantation environment. Implicitly more damage to coastal and marine ecosystems and is unknown (Nofirman, 2017).

Research on abrasion in Bengkulu has been carried out by Suwarsono, Supiyati, and Suwardi (2011) with the aim of examining the characteristics of abrasion speed in each segment of the Jalinbar section of North Bengkulu affected by abrasion. Wahyu Budi Setyawan (2017) examines the problem of eruption of beach cliffs in North Bengkulu. Supiyati, Bakhtiar, and Fatimah (2016) examined the sediment transport caused by longshore current, which resulted in rapid sedimentation at the coast of Teluk Segara District, Bengkulu City. While M. Hasanudin and Edi Kusmanto (2018) conducted a study to identify processes related to abrasion and sedimentation in the coastal area of Bengkulu City.

Based on these studies, it turns out that research has not been carried out on the potential for abrasion in the North Bengkulu coastal area based on the parameters of abrasion susceptibility namely coastal morphology, soil structure and wave height. So this needs to be analyzed further as a disaster mitigation effort. The purpose of this study is to describe the potential for abrasion in the North Bengkulu region based on the parameters of abrasion susceptibility.

\section{RESEARCH METHODS}

The research method used is a qualitative descriptive method with literature studies. The location of this research is in the coastal area of North Bengkulu Regency with three locations, namely Air Petai Beach (Putri Hijau), Urai Beach (Ketahun) and Pasar Palik Beach (Iron Water). The study was conducted based on the parameters of abrasion susceptibility namely coastal morphology, soil structure and wave height.

In the morphology of the beach studied using Landsat image data downloaded from the SAS.Planet.Release. 160707 program. For soil structure, the seismic response measurement using the Multichannel Analysis of Surface Wave (MASW) method was recorded using a 16S24 24 Channels type digital portable seismometer. While the wave height is measured using a Pitometer.

\section{RESULTS AND DISCUSSION}

\section{Coastal Morphology}

Changes in coastal morphology in the area of North Bengkulu Regency based on the geological map presentation results of remote sensing interpretation, image images from the SAS.Planet.Release.160707 program, and the results of observations, found beach conditions as follows:

Air Petai Beach occurs with the undulating terrain morphology facing the sea. Display images from SAS.Planet images seen in sloping beach positions. Abrasion has cut the hill 37 meters high above sea level, so that the morphological shape of the beach occurs with a steep slope $(21 \%-55 \%)$. Based on the cliff outcrop of the hill observed the composition of the Aluvila fan material consisting of gravel, sand, clay and cover soil. As shown in Figure 1. 


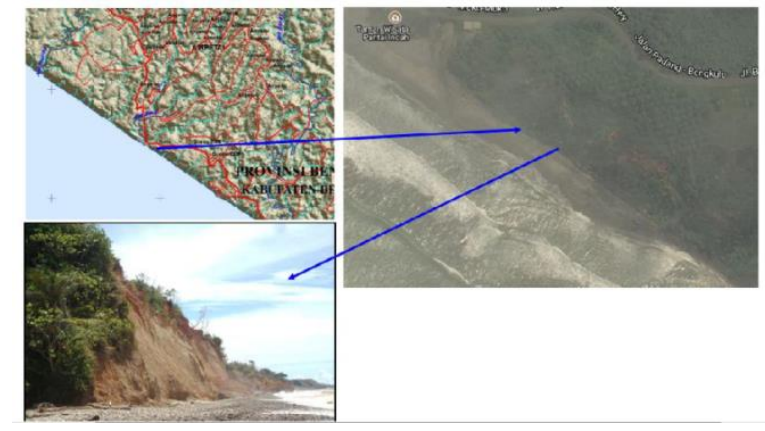

Figure 1. Changes in morphology of the Petai Water Beach - Putri Hijau. Source: Sidarto, 2014, and imagery SAS.Planet.Release.160707.

At Urai beach, the geological condition of the coast is formed from the lithology unit of the Bintunan Formation and the Alluvium unit. The geological landscape forms the morphology of the undulating hillside overlooking the sea. The condition of the beach is seen from the image of SAS. The planet shows that the beach has been cut off by previous abrasion activities. Abrasion activity has made steep cliffs, which are followed by the formation of lightweight coastal caves. The abrasion process produces coastal morphology with a steep slope (21\% -55\%). Based on the outcrops seen, the hill is composed of a conglomerate of various materials, breccias, reef limestone, tuffaceous clay. As shown in Figure 2.

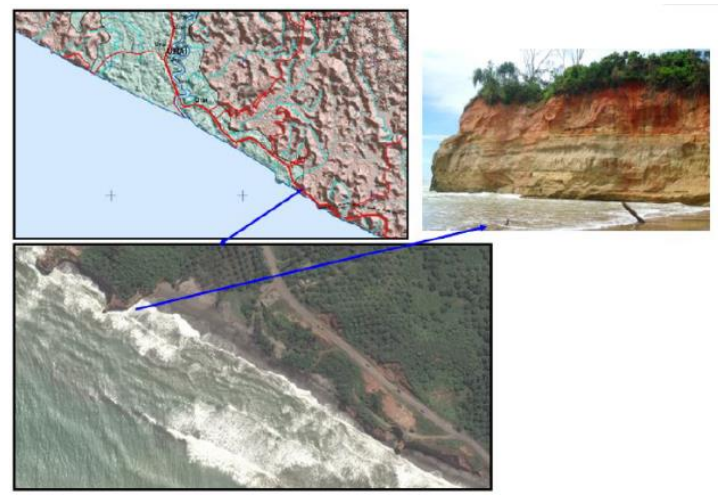

Figure 2. Morphological Changes in Urai Beach - Ketahun. Source: Sidarto, 2014, and imagery SAS.Planet.Release. 160707.

Pasar Palik beach morphology is formed as a slope that forms a bumpy hill with a position facing the sea. The picture seen from the SAS.Planet image shows the condition that the beach has long been cut off by abrasion. Abrasion activity has resulted in steep cliffs that are observed in 4 levels. On this beach also formed Pole (Stack) with the closest distance 78 meters from the beach. Coastal morphology formation due to abrasion makes the slope with a steep slope (21\%-55\%). At the outcrop of the cliff visible arrangement of material forms breccias, clay stones, various conglomerates, and ground cover. As shown in Figure 3. 


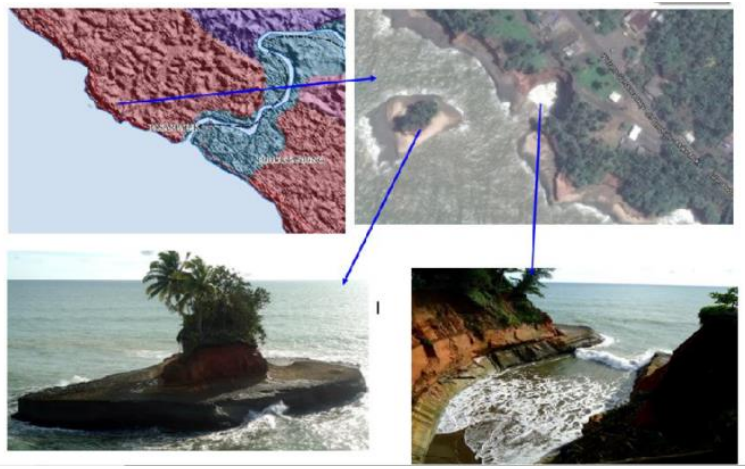

Figure 3. Changes in the morphology of the beach Palik Market - Iron Water. Source: Kusdji, 2014, and imagery SAS.Planet.Release.160707.

\section{Soil Structure}
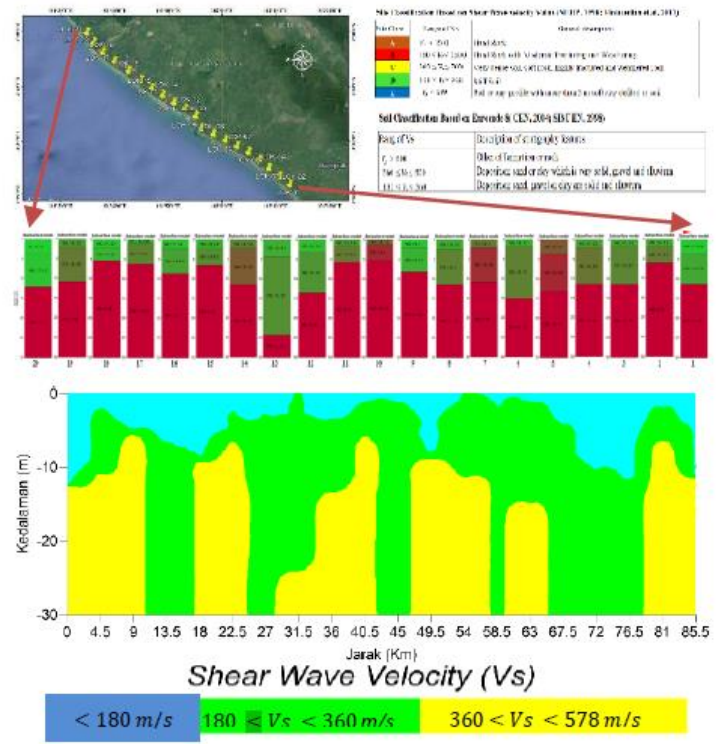

Figure 4. Starting from the top of the map the distribution of MASW measurement points underneath the 1D statigraphic model sequentially from North to South and further below the 2D shear wave velocity stratigraphic model along the coastline of abrasion prone areas in North Bengkulu Regency.

The value of shear wave velocity (Vs) in the abrasion-prone areas of Bengkulu Regency based on the MASW survey is divided into three value groups namely Vs $<180 \mathrm{~m} / \mathrm{s}, 180<\mathrm{Vs}$ $<360 \mathrm{~m} / \mathrm{s}$, and $360<\mathrm{Vs}<760 \mathrm{~m} / \mathrm{s}$. Each of these value groups provides a different picture of the structure and type of rock material. Rock layer which has a value of Vs $<180 \mathrm{~m} / \mathrm{s}$ is estimated to be soil or other profile which is generally a soft clay (soft clay) as a rock compiler. the odor layer that has a value of Vs $180-360 \mathrm{~m} / \mathrm{s}$ is estimated to be rock with a rigid structure or stiff soil and the rock layer which has a value of Vs 360-760 m / s is very dense soil, soft rock and highly fractured weathered rock (Figure 4). The three types of rock layers are soft structured rocks and are estimated to be composed of several types of material, namely sand, gravel, clay and alluvium which vary in density per layer. No indication of hard rock was found to a depth of 30 meters. These three rock layers are soft rock layers which are very susceptible to various 
types of deformations such as crack, settlement, and collapse like the phenomenon of abrasion (Refrizon, 2019).

Wave height

The height of the swash at Urai beach is $75-85 \mathrm{~cm}$, which means the swash energy at this location is greater than Petai Water and Palik Market (Table 1). Urai is a swampy area with surface rocks dominated by peat soils that are very weak against sea water erosion.

Table 1. Wave Height (Swash) at North Bengkulu Location

\begin{tabular}{|c|c|c|}
\hline No & Location & Height $(\mathbf{c m})$ \\
\hline 1 & Air Petai & $58-73$ \\
\hline 2 & Urai & $75-85$ \\
\hline 3 & Pasar Palik & $67-69$ \\
\hline
\end{tabular}

Swash height in Petai Water reaches $58-73 \mathrm{~cm}$. The surface rocks in Air Petai are alluvial deposits and at the bottom they are more resistant to seawater than peat rocks in swamps. While abrasion on the beach Palik with a height of 67-69 $\mathrm{cm}$ swash. This beach has coral reefs and marl, which can block the waves and ocean currents. The swash height of the abrasive location averages $60 \mathrm{~cm}$ even though in certain locations such as Urai the swash height reaches $85 \mathrm{~cm}$ (Suwarsono, 2011).

\section{CONCLUSION}

Based on the results of research conducted in the coastal area of North Bengkulu, it can be concluded that the level of vulnerability of North Bengkulu to abrasion is very large. This can be seen from the abrasion susceptibility parameters, namely the morphology of the North Bengkulu coast in the form of steep cliffs, piles, while steep cliffs also form coastal caves. The soil structure on the beach has a soft structure and is composed of sandstones, gravel, clay and alluvium which vary in density per layer. The differences in rock resistance vertically of each layer produce a beach that is prone to abrasion. The wave height (swash) in the area of North Bengkulu regency is an average of $60 \mathrm{~cm}$ even though in certain locations the height of the swash reaches $85 \mathrm{~cm}$.

\section{REFERENCES}

BNPB. (2014). Indonesian Disaster Risk Index 2013. Sentul: Directorate of Disaster Risk Reduction Deputy for Prevention and Preparedness.

Hasanudin, M., Kusmanto, E. (2018). Beach Abrasion and Sedimentation in the Coastal Area of Bengkulu City. Oceanology and Limnology in Indonesia 2018, 3 (3): 245-252.

Kusdji. (2014). Geological Map Results of Interpretation of Far Lais Bengkulu. Bandung: Geological Survey Center, Geology Agency.

Morton, RA. (2004). An Overview of Coastal Land Loss with Emphasis on the Southeastern United Stated. US Geological Survey, Center for Coastal and Watershed Studies (pp. 03337). St. Petersburg. 
Nofirman, (2017). Changes in Coastal Morphology with Image Integration in North Bengkulu Regency, Georafflesia Journal, Vol: 2, No: 2, December 2017: 42-60.

Refrizon, Sugianto, N., Bernard, A. (2019). Determination of Shear Wave Speed Stratigraphy (VS) in Abrasion-Prone Areas in North Bengkulu Regency using the Multichannel Analysis of Surface Wave (MASW) Method, Journal of Meteorology, Climatology and Geophysics, Vol. 6 No. 2, July 2019: 15-20.

Setiawan, W.B. (2017). Berebing Beach in North Bengkulu: Erosion Problems and Suggestions to Overcome It. Proceedings of the Seminar, September 7, 2017: 182-190.

Sidarto. (2014). Geological Map Results of Interpretation of the Remote Senses of Bengkulu. Bandung: Geological Survey Center, Geology Agency.

Supiyati, Bakhtiar, D., Fatimah, S. (2016). Sediment transport caused by the Longshore Current in the Coast District of Teluk Segara Bengkulu City. Proceedings of the Seminar, Vol: 2, No: 2, December 2017: 11-16.

Suwarsono, Supiyati, Suwardi. (2011). Zoning Characteristics of Abrasion Speed and Design of Handling Techniques in the West Bengkulu North Cross Road as Vital, Makara, Technology Transportation Vol. 15, No. 1, April 2011: 31-38. 